\title{
NEW FELLOWS OF THE ROYAL SOCIETY
}

$\mathbf{A}^{\mathrm{T}}$

T a meeting of the Royal Society on March 20 , the following were elected to fellowships :

MrCHafl ABercrombie, reader in embryology in the University of London at University College, distinguished for his researches in embryology, tissue culture, and wound healing.

Dr. E. P. Abraham, senior research officer at the Sir William Dunn School of Pathology, University of Oxford, distinguished for his work on the isolation and chemistry of antibacterial substances.

DR. J. R. BAKkR, reader in cytology in the University of Oxford, distinguished for his researches on the chemistry of the cell.

Prof. J. A. BIRCh, professor of organic chemistry in the Victoria University of Manchester, distinguished for his studies on the structure and biogenesis of natural products.

Prof. Satyendranath Bose, vice-chancellor of the Visva-Bharati University, Santiniketan, India, distinguished as the discoverer of Bose-Einstein statistics.

Dr. P. W. Brian, head of the Department of Microbiology, Akers Research Laboratories, Imperial Chemical Industries, Ltd., distinguished for his researches on microbiology and plant pathology.

EDITH BÜLBRING, demonstrator in pharmacology in the University of Oxford, distinguished for her work on smooth muscle and on the action of adrenaline.

DR. R. K. CALLOW, research chemist at the National Institute for Medical Research, London, distinguished for his work on steroid chemistry.

Dr. F. DrXey, director of Overseas Geological Surveys, London, distinguished for African geological researches, particularly in tectonics, geomorphology and ground-water hydrology.

Prof. P. P. Ewald, head of the Department of physics in the Polytechnic Institute of Brooklyn, distinguished for his outstanding contributions to the science of X-ray optics.

Prof. F. J. FENNER, professor of microbiology in the Australian National University, Canberra, distinguished for his work on microbiology, particularly the pathogenesis and epidemiology of mousepox and myxomatosis.

DR. W. H. Glanviule, director of the Road Research Laboratory, Department of Scientific and Industrial Research, Harmondsworth, distinguished for his researches on reinforced concrete and on road construction.

Prof. A. E. Green, professor of applied mathematics in the University of Durham (King's College, Newcastle upon Tyne), distinguished for important contributions to the mathematical theory of elasticity and hydrodynamics.
Prof. A. HadDow, professor of experimental pathology in the University of London and director of the Chester Beatty Research Institute (Institute of Cancer Research, Royal Cancer Hospital), distinguished for his investigations into the chemotherapy of malignant disease.

Dr. G. Higman, reader in mathematics in the University of Oxford, distinguished for his contributions to the theory of groups.

Prof. A. St. G. J. McC. HugGetT, professor of physiology in the University of London at St. Mary's Hospital Medical School, distinguished for his investigations on the physiology of reproduction and on the transfer of materials from mother to fotus.

Prof. H. C. Longuet-Higgris, John Humphrey Plummer professor of theoretical chemistry in the University of Cambridge, distinguished for his application of mathematies to problems in physical chemistry.

Prof. B. LythGoe, professor of organic chemistry in the University of Leeds, distinguished for his contributions to the chemistry of natural products.

Prof. S. K. MrTra, professor of physics and director of the Institute of Radio-Physics and Electronics, University of Calcutta, distinguished for his researches in many branches of upper atmosphere physics.

DR. C. H. Mortmer, secretary of the Scottish Marine Biological Association and director of the Marine Laboratory, Millport, distinguished for his research upon lakes and lake-deposits, and the chemical and physical conditions which control life in them.

Prof. R. S. NyноLм, professor of chemistry in the University of London at University College, distinguishod for his contributions to inorganio chemistry, especially for his studies of complex compounds of the transition elements.

Prof. G. D. Rochester, professor of physics in the University of Durham (Durham Colleges), distinguished for his researches on the cosmic radiation, and particularly for his contributions to knowledge of the unstable elementary particles.

Prof. O. A. Saunders, dean of the City and Guilds College and head of the Department of Mechanical Engineering in the Imperial College of Science and Technology, University of London, distinguished for his contributions to the study of heat transfer and to the development of the internal combustion engine.

Prof. J. E. SMITH, professor of zoology in the University of London at Queen Mary College, distinguished for his researches on the principles of nervous organization as exemplified by lower animals.

Dr. W. B. TurRILL, formerly keeper of the herbarium and library at the Royal Botanic Gardens, Kew, distinguished for his experimental and descriptive work on flowering plants of Britain and the Near East. 